\title{
STRATEGI ACTIVE KNOWLEDGE SHARING SETTING PENDEKATAN SAINTIFIK UNTUK MENINGKATKAN SIKAP SISWA TERHADAP MATEMATIKA
}

\section{THE STRATEGY OF ACTIVE KNOWLEDGE SHARING BASED ON SCIENTIVIC APPROACH TO INCREASE STUDENTS' ATTITUDES TOWARD MATHEMATICS}

\author{
LO Amril1a, W Firmansyah', dan RW Wulandari' ${ }^{1}$ \\ 1 Program Studi Pendidikan Guru Sekolah Dasar, Fakultas Keguruan dan Ilmu Pendidikan, \\ Universitas Djuanda Bogor, Jl. Tol Ciawi No. 1 Kotak Pos 35 Ciawi Bogor 16720 \\ a Korespondensi: La Ode Amril, Email: laode.amril27@gmail.com \\ (Diterima: 21-08-2017; Ditelaah: 22-08-2017; Disetujui: 04-10-2017)
}

\begin{abstract}
This study uses a classroom action research design consisting of two cycles. Each cycle there are four stages through which planning, execution, observation and reflection. The subjects of this study are students and teachers of class VIII SMP Negeri 1 Ciawi Bogor. Technique of collecting data using test and non test technique. Data analysis used quantitative descriptive analysis and qualitative descriptive analysis. Implementation of learning is characterized by active knowledge sharing with scientific approach to improve attitude toward mathematics students of class VIII MTs SMP Negeri 1 Ciawi. The active knowledge sharing strategy allows students to actively share their knowledge. Competition among students can be reduced because students are taught to help each other friends in terms of learning activities. Students are directed to think critically and creatively in solving the given mathematical problems. In addition to the level of attitudes toward mathematics, students 'cognitive abilities also increased, but the percentage increase in students' attitudes toward mathematics is greater than the percentage of student cognitive improvement.
\end{abstract}

Keywords: active knowledge sharing, attitude toward mathematics, scientific approach.

\begin{abstract}
ABSTRAK
Penelitian ini menggunakan rancangan penelitian tindakan kelas yang terdiri atas dua siklus. Setiap siklus terdapat empat tahapan yang dilalui yaitu perencanaan, pelaksanakan, pengamatan dan refleksi. Subjek penelitian ini adalah siswa dan guru kelas VIII SMP Negeri 1 Ciawi Bogor. Teknik pengumpulan data menggunakan teknik tes dan non tes. Analisis data menggunakan analisis deskriptif kuantitatif dan analisis deskripstif kualitatif. Penerapan pembelajaran bercirikan active knowledge sharing dengan pendekatan saintifik meningkatkan sikap terhadap matematika siswa kelas VIII MTs SMP Negeri 1 Ciawi. Strategi active knowledge sharing memberikan kesempatan kepada siswa untuk saling berbagi pengetahuan secara aktif. Kompetisi antar peserta didik dapat dikurangi karena siswa diajarkan untuk saling membantu teman dalam hal kegiatan belajar. Siswa diarahkan untuk berpikir kritis dan kreatif dalam menyelesaikan permasalahan matematika yang diberikan. Selain pada tingkat sikap terhadap matematika, kemampuan kognitif siswa juga mengalami peningkatan, namun persentase kenaikan kemampuan sikap siswa terhadap matematika lebih besar daripada persentase kenaikan kognitif siswa.
\end{abstract}

Kata kunci: active knowledge sharing, pendekatan saintifik, sikap terhadap matematika. 
Amril LO, W Firmansyah, dan RW Wulandari. 2017. Strategi active knowledge sharing setting pendekatan saintifik untuk meningkatkan sikap siswa terhadap matematika. Jurnal Sosial Humaniora 8(2): 93 - 103.

\section{PENDAHULUAN}

Kegiatan pembelajaran merupakan proses pengubahan tingkah laku peserta didik melalui pengoptimalan lingkungan sebagai sumber stimulus belajar. Peraturan Pemerintah nomor 19 tahun 2005 pasal 19 ayat 1 tentang Standar Nasional Pendidikan menjelaskan bahwa proses pembelajaran harus dilaksanakan secara interaktif, inspiratif, menyenangkan, menantang, dan memotivasi peserta didik (Kemendiknas 2005). Berdasarkan hasil observasi saat prapenelitian di SMP Negeri 1 Ciawi, menunjukkan adanya permasalahan pada pembelajaran matematika. Selama ini RPP matematika yang disusun oleh guru belum memfasilitasi siswa untuk mengembangkan keterampilan pemecahan masalah. RPP yang digunakan oleh guru belum menggunakan penilaian hasil belajar yang meliputi sikap, pengetahuan, dan keterampilan tersebut dengan baik. Hal ini disebabkan karena penilaian yang digunakan lebih cenderung menilai aspek kognitif saja.

Pra-penelitian pada aspek afektif siswa kelas VIII SMP Negeri 1 Ciawi antara lain menyangkut sikap terhadap matematika. Pra-penelitian dilaksanakan pada hari senin tanggal 20 Januari 2016 dengan memberikan angket kepada 32 siswa. Angket tersebut berupa pernyataan-pernyataan yang berhubungan dengan sikap siswa terhadap matematika. Hasil angket sikap siswa terhadap matematika pada saat prapenelitian terdapat pada Tabel 1 .

Berdasarkan tabel 1, maka ada indikasi bahwa terdapat siswa-siswa yang kurang menyenangi pembelajaran matematika. Hal ini didukung dengan hasil wawancara guru bahwa dalam kegiatan pembelajaran matematika masih ditemui siswa-siswa yang kurang memperhatikan dalam kegiatan pembelajaran, mengganggu teman, tidak mengerjakan tugas, serta tidak fokus dalam pembelajaran.

Tabel 1 Hasil angket sikap terhadap matematika pada saat prapenelitian

\begin{tabular}{llr}
\hline \multicolumn{1}{c}{ Interval } & \multicolumn{1}{c}{ Kriteria } & \multicolumn{1}{c}{$\begin{array}{c}\text { Kondisi } \\
\text { Awal }\end{array}$} \\
\hline$X>184,79$ & Sangat baik & $21,87 \%$ \\
$149,6<X \leq 184,79$ & Baik & $71,87 \%$ \\
$114,4<X \leq 149,6$ & Cukup & $0 \%$ \\
$79,21<X \leq 1144$ & Kurang & $6,25 \%$ \\
$X \leq 79,21$ & Sangat & $0 \%$ \\
\hline
\end{tabular}

Guru perlu mengembangkan berbagai kegiatan belajar yang melibatkan siswa secara aktif dan menantang kreatifitas siswa. Hosnan (2014) menjelaskan bahwa pembelajaran aktif (active learning) adalah kegiatan belajar dengan menggunakan seluruh potensi yang dimiliki peserta didik secara optimal, dengan tujuan agar mereka dapat mencapai hasil belajar yang memuaskan sesuai dengan karakteristik kepribadian yang dimiliki oleh siswa. Hal tersebut sesuai dengan Peraturan Pemerintah nomor 68 tahun 2013 tentang proses pembelajaran yang mengubah pola pembelajaran pasif menjadi pembelajaran aktif-mencari dimana siswa aktif membangun pengetahuannya yang diperkuat dengan model pembelajaran pendekatan saintifik (Kemendikbud 2013).

Pendekatan yang digunakan dalam Kurikulum 2013 yaitu pendekatan saintifik. Komara (2014) menjelaskan bahwa melalui pendekatan saintifik diharapkan siswa memiliki kompetensi sikap, pengetahuan dan keterampilan jauh lebih baik. Mereka akan lebih kreatif, inovatif, dan lebih produktif, sehingga nantinya mereka bisa sukses dalam menghadapi berbagai persoalan dan tantangan di zamannya, memasuki masa depan yang lebih baik. 
Menurut Atkin dan Black (2003) "Problem solving as the core of scientific method and also for his emphasis on studies of the student's own community". Tujuan dari penelitian ini yakni (1) meningkatkan sikap siswa terhadap matematika siswa melalui strategi Active Knowledge Sharing seting pendekatan saintifk di SMP 1 Ciawi; (2) mendeskripsikan peningkatan sikap siswa terhadap matematika SMP Negeri 1 Ciawi dengan adanya penerapan strategi Active Knowledge Sharing dengan pendekatan saintifk; (3) meningkatkan pengetahuan matematika siswa melalui strategi Active Knowledge Sharing seting pendekatan saintifk di SMP Negeri 1 Ciawi; dan (4) mendeskripsikan peningkatan pengetahuan matematika siswa SMP Negeri 1 Ciawi dengan adanya penerapan strategi Active Knowledge Sharing seting pendekatan saintifik.

\section{MATERI DAN METODE}

\section{Subjek Penelitian}

Subjek penelitian ini adalah siswa kelas VIII A SMP Negeri 1 Ciawi Bogor pada semester ganjil Tahun Ajaran 2017 - 2018.

\section{Waktu dan tempat}

Penelitian ini dilakukan di SMP Negeri 1 Ciawi Bogor Jawa Barat di kelas VIII A pada semester ganjil tahun ajaran 2017-2018.

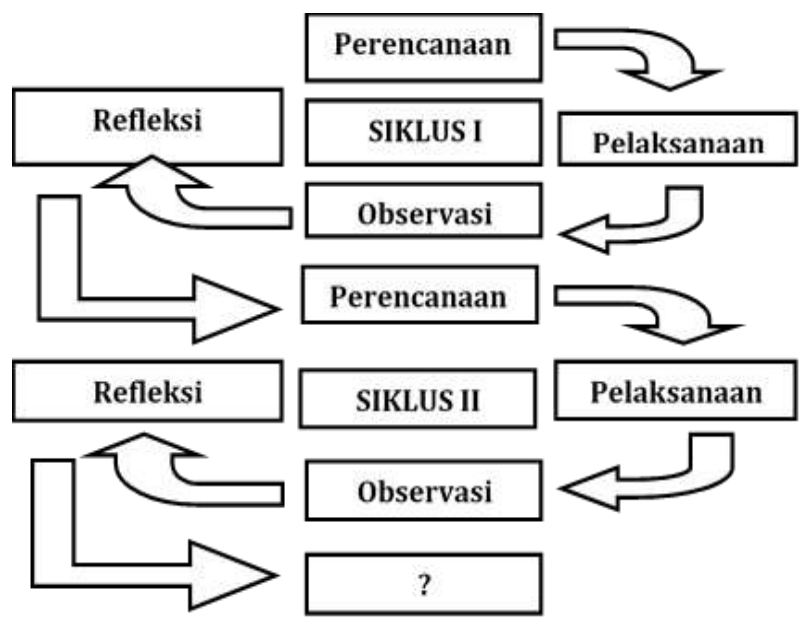

Gambar 1 Alur penelitian tindakan

\section{Metode Penelitian}

penelitian ini merupakan Penelitian Tindakan Kelas (Classroom Action Research) yang biasa disingkat PTK. Prosedur penelitian dapat digambarkan seperti pada Gambar 1.

\section{Jenis Tindakan}

Adapun prosedur atau langkah-langkah tindakan dalam penelitian ini adalah sebagai berikut.

\section{Siklus 1}

\section{Perencanaan}

Perencanaan umum yang dilakukan oleh peneliti dengan guru adalah bagaimana peneliti dan guru memahami peran masingmasing, proses implementasi pendekatan saintifik dengan strategi active knowledge sharing yang akan dilakukan, evaluasi yang diperlukan, hasil yang diharapkan, proses monitoring, dan observasi.

Untuk memperlancar tindakan, peneliti bersama guru mempersiapkan instrumen pembelajaran, antara lain berupa silabus dan sistem penilaian, Rencana Pembelajaran (RP), Lembar Kerja Siswa (LKS) serta soal evaluasi yang dibuat oleh peneliti yang kemudian dikonsultasikan dengan guru mata pelajaran matematika. Peneliti juga mempersiapkan isntrumen penelitian, yang digunakan sebagai alat pengumpul data. Instrument yang digunakan adalah: lembar observasi, angket, lembar observasi keterlaksanaan pembelajaran, dan dokumentasi.

\section{Tindakan}

Tindakan yang dilakukan adalah menerapkan pembelajaran matematika dengan pendekatan saintifik dengan strategi active knowledge sharing, yang disajikan oleh guru bidang studi matematika, sedang peneliti berperan sebagai observer.

\section{Observasi}

Peneliti perlu mengamati beberapa hal antara lain: proses tindakan, pengaruh tindakan (baik yang disengaja maupun yang tidak disengaja), keadaan dan kendala 
tindakan, serta persoalan lain yang timbul. Untuk mempermudah observasi peneliti menggunakan lembar observasi sebagai panduan, serta membuat catatan lapangan.

\section{Refleksi}

Peneliti berusaha mengingat kembali dan merenungkan suatu tindakan persis yang telah dicatat dalam observasi. Refleksi dilakukan dengan melakukan diskusi antara peneliti dengan guru. Berdasarkan hasil refleksi dilakukan perbaikan-perbaikan yang akan dilaksanakan untuk siklus selanjutnya.

Tindakan siklus 2, dilakukan berdasarkan perencanaan dan perbaikan dari hasil refleksi siklus sebelumnya, kemudian dilakukan refleksi untuk melihat sejauh mana perubahan yang terjadi melalui tindakan kedua. Demikian seterusnya sampai kriteria keberhasilan tercapai.

\section{Teknik Analisis Data}

\section{Analisis data hasil angket sikap terhadap matematika}

Hasil dari angket sikap terhadap matematika yang diberikan sebelum tindakan, sesudah siklus 1, dan sesudah siklus 2 mencerminkan seberapa besar sikap yang dimiliki siswa terhadap matematika. Indikator peningkatan sikap siswa terhadap matematika dilihat dengan membandingkan analisis hasil angket tersebut sebelum tindakan dan pada tiap akhir siklus. Data yang terkumpul dianalisis dengan cara-cara sebagai berikut.

a. Memberikan skor pada tiap-tiap pernyataan yang telah diisi siswa. Skor ini dibedakan berdasarkan pernyataan negatif dan positif, yang kemudian dijumlahkan untuk masing-masing siswa.

b. Mengategorikan total skor sikap terhadap matematika dari masingmasing siswa. Skor yang diperoleh dalam bentuk kuantitatif kemudian dikonversikan menjadi data kualitatif berdasarkan Tabel 2 (Widoyoko 2009).

c. Total skor sikap siswa terhadap matematika juga dihitung persentase total dan rata-rata keseluruhan, guna melihat ketercapaian dari target yang diinginkan. Penelitian ini dikatakan berhasil jika 75\% dari seluruh siswa telah mencapai kategori minimal Baik.

Tabel 2 Kriteria konversi data kuantitatif ke data kualitatif

\begin{tabular}{lll}
\hline \multicolumn{1}{c}{ Nilai } & \multicolumn{1}{c}{ Interval Skor } & \multicolumn{1}{c}{ Kategori } \\
\hline A & $X>\bar{X}_{l}+1,8 s b_{i}$ & Sangat Baik \\
B & $\bar{X}_{l}+0,6 s b_{i}<X \leq \bar{X}_{l}+1,8 s b_{i}$ & Baik \\
C & $\bar{X}_{l}-0,6 s b_{i}<X \leq \bar{X}_{l}+0,6 s b_{i}$ & Cukup \\
D & $\bar{X}_{l}-1,8 s b_{i}<X \leq \bar{X}_{l}-0,6 s b_{i}$ & Kurang \\
E & $X \leq \bar{X}_{l}-1,8 s b_{i}$ & Sangat Kurang \\
\hline
\end{tabular}

Keterangan: $S b_{i}=$ Standar Deviasi Ideal ( $\frac{\text { skor maksimum - skor minimum }}{6}$ );X = Skor Aktual;

$X_{i}=$ Rata-rata Ideal $\left(\frac{\text { skor maksimum+skor minimum }}{2}\right)$

\section{Analisis data tes akhir siklus}

Tes akhir siklus yang berupa pilihan ganda dianalisis dengan cara menghitung skor total yang dicapai oleh masing-masing siswa. Skor ini selanjutnya dibandingkan dengan KKM (Kriteria Ketuntasan Minimal) yang telah ditentukan oleh pihak sekolah. Penelitian ini dikatakan berhasil jika 80\% dari seluruh siswa telah mencapai KKM.
Validitas dan Reliabilitas Instrumen

\section{Reliabilitas Intrumen}

\section{Reliabilitas Instrumen Angket}

Hasil estimasi reliabilitas instrumen angket menggunakan cronbach's alpha dengan bantuan SPSS. Hasil estimasi tersebut dapat dilihat pada Tabel 3. 
Tabel 3 Hasil estimasi reliabilitas instrumen

\begin{tabular}{rrr}
\hline \multicolumn{3}{c}{ Reliability Statistics } \\
\hline $\begin{array}{c}\text { Cronbach's } \\
\text { Alpha }\end{array}$ & $\begin{array}{c}\text { Cronbach's Alpha } \\
\text { Based on } \\
\text { Standardized Items }\end{array}$ & $\begin{array}{c}\text { N of } \\
\text { Items }\end{array}$ \\
\hline, 894 & \multicolumn{293}{c}{44} \\
\hline
\end{tabular}

Dari hasil output SPSS menunjukan bahwa nilai cronbach's alpha yang diperoleh adalah 0,894 . Karena bernilai 0,894 lebih dari 0,70 maka dapat dikatakan bahwa instrumen angket sikap siswa terhadap matematika reliabel. Output SPPS hasil uji reliabilitas selengkapnya dapat dilihat pada lampiran.

\section{Reliabilitas Instrumen Tes}

Proses estimasi reliabilitas instrumen tes hasil belajar dapat dilihat pada lampiran 2 . Berdasarkan hasil estimasi diperoleh koefisien reliabilitas instrument tes hasil belajar 0,81. Karena nilai reliabilitas yang diperoleh lebih dari 0,70 maka dapat disimpulkan bahwa instrument telah memenuhi kriteria reliabel.

\section{Validitas Intrumen}

\section{Validitas Instrumen Angket}

1. Validitas Isi

Instrumen angket sikap siswa terhadap matematika menggunakan bukti validitas isi dan validitas konstruks. Seperti pada instrumen tes, peneliti menggunakan expert judgment untuk menyediakan bukti validitas isi. Dalam hal ini, ahli berasal dua orang dosen dari FKIP Universitas Djuanda Bogor, yakni Dr. Widyasari, M.Pd dan Wita Ratna Puspita, M.Pd. Bukti validitas isi untuk intrumen angket sikap siswa terhadap matematika selengkapnya dapat dilihat pada lampiran C-3. Berdasarkan hasil dari expert judgment dapat disimpulkan bahwa istrumen angket sikap siswa terhadap matematika valid.

2. Validitas Konstruk

Validitas konstruk mengacu pada sejauh mana trait angket penelitian mengukur konstruk dari sikap siswa terhadap matematika. Analisis ini menggunakan bantuan SPSS. Hasil uji validitas konstruk dapat dilihat pada Tabel 4 .

Tabel 4 Hasil uji validitas konstruk

\begin{tabular}{llr}
\hline \multicolumn{3}{c}{ KMO and Bartlett's Test } \\
\hline $\begin{array}{l}\text { Kaiser-Meyer-Olkin Measure of } \\
\text { Sampling Adequacy. }\end{array}$ &, 769 \\
Bartlett's Test & Approx. Chi- & 302,703 \\
of Sphericity & Square & 190 \\
& Df &, 000 \\
\hline
\end{tabular}

Dari hasil analisis diperoleh nilai kaiser meyer olkin measure of sampling adequacy pada kotak KMO and Bartlet's Test adalah sebesar 0.566 hasil ini memperlihatkan bahwa instrumen ini valid karena KMO telah melebihi dari 0,5. Di samping itu dilihat dari nilai bartlett. Test menunjukkan nilai dengan signifikan 0.000 sehingga dapat disimpulkan bahwa instrumen ini telah memenuhi syarat valid.

\section{Validitas Instrumen Tes}

Bukti validitas isi untuk instrumen tes hasil belajar matematika dan tes kemampuan representasi matematis diperoleh berdasarkan expert judgement. Dalam hal ini ahli berasal dua orang dosen dari FKIP Universitas Djuanda Bogor, yakni Dr. Widyasari, M.Pd dan Wita Ratna Puspita, M.Pd.

\section{HASIL DAN PEMBAHASAN}

\section{Hasil}

\section{Siklus I}

Selama pelaksanaan pembelajaran pada siklus I peneliti selalu melakukan observasi, baik kepada guru maupun kepada siswa. Observasi dilakukan dengan menggunakan lembar observasi keterlaksanaan pembelajaran yang telah dibuat. Observasi selalu dilakukan di setiap pertemuan pada siklus I yang terdiri dari empat kali pertemuan. Untuk memperjelas hasil 
observasi pada siklus I berikut ini disajikan ringkasan hasil observasi pada siklus I.

\section{Hasil observasi keterlaksanaan pembelajaran}

Dari pertemuan pertama sampai keempat guru kurang memotivasi siwa dengan mengaitkan materi dengan sumber belajar yang ada di lingkungan sekitar. Pada pertemuan pertama dan kedua guru belum menyampaikan garis besar materi yang akan dipelajari, namun pada pertemuan ke tiga dan keempat guru sudah menyampaikan garis besar materi yang akan dipelajari. Guru belum memberi informasi kepada siswa tentang LKS yang akan diberikan. Hanya pada pertemuan keempat muncul. Guru belum memberikan informasi kepada siswa mengenai alat/bahan yang diperlukan untuk mengerjakan LKS.

Siswa belum terbiasa mengajukan pertanyaan tentang informasi yang tidak dipahami dari apa yang diamati. Tidak semua kelompok memberikan tanggapan terhadap presentasi kelompok lain.
Kesadaran siswa untuk saling bertukar informasi masih kurang. Kebanyakan siswa kurang aktif dalam mencari informasi dari teman untuk membantu dalam menjawab pertanyaan. Terkadang tidak ada waktu untuk memberikan tugas terkait dengan materi yang sudah dipelajari karena keterbatasan waktu.

Hasil observasi keterlaksanaan pembelajaran pada pertemuaan keempat menunjukkan hasil $83 \%$ kegiatan pembelajaran terlaksana. Hasil tersebut sudah mencapai target keterlaksanaan minimal $80 \%$ namun masih perlu untuk ditingkatkan lagi.

\section{Hasil pengisian angket sikap terhadap matematika}

Guna mendapatkan data tentang sikap siswa terhadap matematika, peneliti juga memberikan angket kepada siswa. Angket diberikan sebelum tindakan dilaksanakan dan sesuah tindakan pada siklus I. Tabel 5 menunjukkan hasil perhitungan persentase angket sikap siswa terhadap matematika.

Tabel 5 Hasil perhitungan persentase angket sikap siswa terhadap matematika siklus I

\begin{tabular}{llrrr}
\hline \multicolumn{1}{c}{ Interval } & \multicolumn{1}{c}{ Kriteria } & Kondisi Awal & Target & Akhir Siklus I \\
\hline $\mathrm{X}>184,79$ & Sangat baik & $21,87 \%$ & $25 \%$ & $15,62 \%$ \\
$149,6<\mathrm{X} \leq 184,79$ & Baik & $71.87 \%$ & $75 \%$ & $72,00 \%$ \\
$114,4<\mathrm{X} \leq 149,6$ & Cukup & $0 \%$ & $0 \%$ & $9,38 \%$ \\
$79,21<\mathrm{X} \leq 114,4$ & Kurang & $6,25 \%$ & $0 \%$ & $3 \%$ \\
$\mathrm{X} \leq 79,21$ & Sangat kurang & $0 \%$ & $0 \%$ & $0 \%$ \\
\multicolumn{1}{c}{ Rata-rata } & & 150,2 (Baik) & & 162,63 (Baik) \\
\hline
\end{tabular}

Berdasarkan tabel 5 dapat diketahui bahwa hasil angket sikap siswa terhadap matematika menunjukkan kategori baik dengan rata-rata skor 162,63 . Siswa yang memperoleh kriteria baik yaitu 71,87\%. Jika dibandingkan dengan sebelum pelaksanaan tindakan sikap matematika siswa mengalami peningkatan sebesar 8,3\%. Hasil tersebut belum mencapai target yang diharapkan yaitu siswa yang memperoleh kategori baik minimal $75 \%$.

\section{Hasil tes kognitif}

Hasil tes kognitif siswa kelas VIII D pada mata pelajaran matematika melalui penerapan pembelajaran active knowledge sharing dengan pendekatan saintifik pada siklus I diperoleh dari hasil tes setelah melaksanakan empat kali pertemuan. Jumlah siswa yang mengikuti pembelajaran sebanyak 32 siswa. Data yang diperoleh disajikan dalam tabel 6 . 
Tabel 6 Hasil tes kognitif siklus I

\begin{tabular}{lrr}
\hline \multirow{2}{*}{ Aspek } & \multicolumn{2}{c}{ Siklus I } \\
\cline { 2 - 3 } & \multicolumn{1}{c}{ Pre-tes } & \multicolumn{1}{c}{ Post-tes } \\
\hline Rata-rata kelas & 50,81 & 82,28 \\
Nilai tertinggi & 62 & 92 \\
Nilai terendah & 32 & 66 \\
Tuntas & 0 & 25 \\
Belum Tuntas & 32 & 7 \\
Persentase & $0 \%$ & $78,13 \%$ \\
Ketuntasan & & \\
\hline
\end{tabular}

Berdasarkan tabel 6 dapat diketahui bahwa setelah diberikan tindakan kelas pada siklus I, tes hasil belajar kognitif siswa memperoleh skor rata-rata kelas 82,28. Jumlah siswa yang memperoleh skor di atas 75 adalah 78,13\%. Hasil tersebut belum mencapai target yang diharapkan yaitu ketuntasan belajar minimal $80 \%$ sehingga perlu dilaksanakan siklus berikutnya dengan segala perbaikan.

\section{Siklus II}

\section{Hasil observasi keterlaksanaan pembelajaran}

Dari pertemuan pertama sampai ketiga guru kurang memotivasi siwa dengan mengaitkan materi dengan sumber belajar yang ada di lingkungan sekitar. Pada pertemuan pertama dan kedua guru belum menyampaikan garis besar materi yang akan dipelajari, namun pada pertemuan ke tiga guru sudah menyampaikan garis besar materi yang akan dipelajari. Guru belum memberi informasi kepada siswa tentang LKS yang akan diberikan. Hanya pada pertemuan ketiga yang muncul. Guru belum memberikan informasi kepada siswa mengenai alat/bahan yang diperlukan untuk mengerjakan LKS.

Siswa belum terbiasa mengajukan pertanyaan tentang informasi yang tidak dipahami dari apa yang diamati. Tidak semua kelompok memberikan tanggapan terhadap presentasi kelompok lain. Kesadaran siswa untuk saling bertukar informasi masih kurang. Kebanyakan siswa kurang aktif dalam mencari informasi dari teman untuk membantu dalam menjawab pertanyaan. Terkadang tidak ada waktu untuk memberikan tugas terkait dengan materi yang sudah dipelajari karena keterbatasan waktu. Hasil observasi keterlaksanaan pembelajaran pada pertemuaan kedelapan menunjukkan hasil 96\% kegiatan pembelajaran terlaksana. Hasil tersebut sudah mencapai target keterlaksanaan minimal $80 \%$.

\section{Hasil pengisian angket sikap terhadap matematika}

Guna mendapatkan data tentang sikap siswa terhadap matematika, peneliti juga memberikan angket kepada siswa. Angket diberikan sebelum tindakan dilaksanakan dan sesuah tindakan pada siklus II. Hasil perhitungan persentase angket sikap siswa terhadap matematika terdapat pada Tabel 7.

Tabel 7 Hasil pengisian angket sikap terhadap matematika siklus II

\begin{tabular}{llrrrr}
\hline \multicolumn{1}{c}{ Interval } & \multicolumn{1}{c}{ Kriteria } & Kondisi Awal & Target & Akhir Siklus I & Akhir Siklus II \\
\hline $\mathrm{X}>184,79$ & Sangat baik & $21,87 \%$ & $25 \%$ & $15,62 \%$ & $21,88 \%$ \\
$149,6<\mathrm{X} \leq 184,79$ & Baik & $71,87 \%$ & $75 \%$ & $75,00 \%$ & $78,12 \%$ \\
$114,4<\mathrm{X} \leq 149,6$ & Cukup & $0 \%$ & $0 \%$ & $9,38 \%$ & \\
$79,21<\mathrm{X} \leq 114,4$ & Kurang & $6,25 \%$ & $0 \%$ & $0 \%$ & \\
$\mathrm{X} \leq 79,21$ & Sangat kurang & $0 \%$ & $0 \%$ & $0 \%$ & \\
Rata-rata & & 150,2 (Baik) & & 162,63 (Baik) & 177,25 (Baik) \\
\hline
\end{tabular}

Berdasarkan tabel 7 tersebut dapat diketahui bahwa sikap siswa terhadap matematika sudah lebih baik jika dibandingkan dengan sebelum pelaksanaan tindakan, yaitu mengalami peningkatan rata- rata skor sebesar 27,05 dari 150,2 menjadi 177,25 dengan kategori baik.

\section{Hasil tes kognitif}

Hasil tes kognitif siswa kelas VIII D pada mata pelajaran matematika melalui 
penerapan pembelajaran active knowledge sharing dengan pendekatan saintifik pada siklus II diperoleh dari hasil tes setelah melaksanakan tiga kali pertemuan. Jumlah siswa yang mengikuti pembelajaran sebanyak 32 siswa. Data yang diperoleh disajikan dalam tabel 8.

Tabel 8 Hasil belajar siswa siklus II

\begin{tabular}{lrrrr}
\hline \multirow{2}{*}{ Keterangan } & \multicolumn{2}{c}{ Siklus I } & \multicolumn{2}{c}{ Siklus II } \\
\cline { 2 - 5 } & \multicolumn{1}{c}{ Pre-tes } & Post-tes & Pre-tes & Post-tes \\
\hline Rata-rata kelas & 50,81 & 82,28 & 51.67 & 82,79 \\
Nilai tertinggi & 62 & 92 & 62 & 95 \\
Nilai terendah & 32 & 66 & 32 & 70 \\
Tuntas & 0 & 25 & 0 & 27 \\
Belum Tuntas & 32 & 7 & 32 & 5 \\
Persentase Ketuntasan & $0 \%$ & $78,13 \%$ & $0 \%$ & $84,37 \%$ \\
\hline
\end{tabular}

Berdasarkan tabel 8, dapat diketahui bahwa Hasil belajar kognitif siswa juga sudah jauh lebih baik dibandingkan dengan sebelum pelaksanaan tindakan, dimana ratarata kelas adalah 82,79. Jumlah siswa yang memperoleh skor di atas 75 lebih dari 80\% yaitu sejumlah 27 siswa $(84,37 \%)$.

\section{Pembahasan}

Penelitian ini dilaksanakan dengan menerapkan pendekatan saintifik dengan strategi active knowledge sharing pada pembelajaran matematika kelas VIII SMP Negeri 1 Ciawi. Selanjutnya peneliti memaparkan pembahasan hasil penelitian meliputi pemaknaan temuan yang digunakan untuk memahami hubungan dan konsep dalam data sehingga dapat diperoleh kesimpulan.

\section{Penerapan Strategi Pembelajaran Active Knowledge Sharing dengan Pendekatan Saintifik}

Pembelajaran dengan menerapkan pendekatan saintifik dapat diartikan sebagai proses pembelajaran berbasis proses keilmuan. Siswa belajar melalui kegiatan pengamatan, penalaran, penemuan, pengabsahan, dan penjelasan tentang suatu kebenaran. Sehingga melalui kegiatan pembelajaran tersebut diharapkan siswa dapat membangun pengetahuan secara mandiri. Siswa diarahkan agar aktif dalam proses pembelajaran melalui langkah- langkah kegiatan mulai dari mengamati, menanya, mengumpulkan informasi, menalar, dan mengkomunikasikan.

Pembelajaran active knowledge sharing merupakan salah satu strategi pembelajaran aktif yang dapat mendorong siswa dalam menambah pengetahuan melalui kegiatan saling berbagi informasi dengan teman secara aktif. Melalui kegiatan active knowledge sharing, guru dapat meningkatkan kemampuan komunikasi dan keterampilan interpersonal. Siswa juga diajarkan untuk menghargai ide dan sudut pandang yang beragam dari siswa lain. Siswa diarahkan agar saling membantu teman untuk belajar memecahkan masalah sehingga menimbulkan sikap positif dalam belajar matematika.

Langkah pembelajaran active knowledge sharing dengan pendekatan saintifik yang dilaksanakan dalam pembelajaran matematika yaitu: 1) siswa mengamati permasalahan yang diberikan oleh guru; 2) siswa mengajukan pertanyaan tentang informasi yang tidak dipahami dari apa yang diamati; 3) guru mendaftar pertanyaan yang diajukan oleh siswa dan menyaring pertanyaan sesuai dengan materi yang akan dipelajari; 4) guru memberikan dafar pertanyaan yang mengandung materi yang akan diajarkan; 5) siswa berusaha menjawab pertanyaan dengan sebaik-baiknya; 6) siswa diajak untuk berkeliling ruangan, mencari informasi dari siswa lain untuk menjawab berbagai pertanyaan yang tidak siswa 
ketahui bagaimana menjawabnya; 7) siswa kembali ketempat duduk masing-masing kemudian mengolah informasi yang berhasil dikumpulkan di dalam kelompok; 8) masingmasing kelompok menyampaikan kesimpulan berdasarkan hasil diskusi; dan 9) guru memberikan jawaban untuk pertanyaan yang tidak bisa dijawab oleh siswa dan menggunakan informasi itu untuk memperkenalkan topik-topik penting.

Pada saat kegiatan mengamati permasalahan, siswa diajarkan untuk berpikir kritis dan menuliskan hasil pengamatan yang kemudian diharapkan muncul rasa ingin tahu dari diri siswa. Melalui kegiatan menanya siswa dapat berlatih untuk berpikir kreatif dalam menyusun pertanyaan yang ingin diketahui sehingga dapat meningkatkan rasa ingin tahunya. Dengan berbagi informasi dengan teman, siswa lebih mudah dalam menyelesaikan masalah yang dihadapi. Melalui kegiatan diskusi kelompok, siswa belajar untuk melihat kembali informasi yang berhasil diperoleh dan mengolah informasi tersebut untuk menyelesaikan permasalahan yang diberikan. Selain itu, kegiatan pembelajaran dapat memfasilitasi siswa untuk berpartisipasi aktif dalam mengutarakan pendapat.

Tujuan utama pembelajaran active knowledge sharing dengan pendekatan saintifik adalah agar siswa terbiasa untuk saling berbagi pengetahuan dalam memecahkan masalah. Dengan demikian kegiatan pembelajaran dapat meningkatkan kemampuan kognitif serta sikap positif siswa terhadap matematika. Selama pembelajaran dapat diketahui bahwa keunggunalan pembelajaran active knowledge sharing dengan pendekatan saintifik adalah sebagai berikut.

a. Siswa dapat berbagi pengetahuan dengan teman secara lebih aktif untuk menyelesaikan permasalahan yang diberikan. Siswa menuliskan informasi yang diperoleh dari siswa lain.

b. Kompetisi antar peserta didik dapat dikurangi karena siswa diajarkan untuk saling membantu teman dalam hal kegiatan belajar.

c. Siswa diarahkan untuk berpikir kritis dan kreatif dalam menyelesaikan permasalahan matematika yang diberikan.

d. Siswa aktif dalam membangun pengetahuan secara mandiri.

e. Siswa diberikan kebebasan untuk mencari informasi dari berbagai sumber untuk menambah pengetahuan mereka.

f. Siswa dapat belajar memecahkan masalah dalam kehidupan sehari-hari yang terkait dengan matematika.

\section{Sikap terhadap Matematika}

Sikap terhadap matematika merupakan respon individual siswa terhadap matematika yang menggambarkan perasaan positif dan negatif, melibatkan apa yang siswa pikirkan, apa yang siswa rasakan, dan bagaimana mereka bersikap. Jika siswa memilih yang baik maka dia memiliki sikap positif dan jika memilih sesuatu yang buruk maka dikatakan memiliki sikap negatif. Sikap positif terhadap matematika merupakan hal penting yang harus dimiliki siswa. Dengan adanya sikap positif terhadap matematika maka siswa cenderung lebih semangat dalam belajar matematika dan memberikan dampak positif terhadap kemampuan kognitif siswa.

Kegiatan belajar yang terjadi selama proses tindakan dilakukan sesuai tujuan dari pembelajaran dengan pendekatan saintifik dan strategi active knowledge sharing. Pembelajaran dirasakan guru dapat meningkatkan sikap positif terhadap matematika. Peningkatan skor sikap positif terhadap matematika yang diperoleh dari hasil angket siswa pada kondisi awal, akhir siklus I, dan akhir siklus II terdapat pada Tabel 9.

Penyebaran angket sikap terhadap matematika dilakukan pada akhir siklus, guna memperoleh data tentang sikap siswa terhadap matematika saat siklus sebelumnya. Data hasil pengisian angket menunjukkan bahwa sikap siswa terhadap 
matematika mengalami peningkatan. Pada kondisi awal rata-rata skor yang diperoleh siswa 150,2 dengan kategori baik. Skor tersebut meningkat pada akhir siklus I yaitu 162,63 dengan kategori baik. Pada siklus II skor yang diperoleh meningkat menjadi 177,25 dengan kategori baik. Terdapat peningkatan skor rata-rata 8,3\% pada akhir sklus I dan 18\% pada akhir siklus II jika dibandingkan dengan kondisi awal. Hal ini menunjukkan bahwa penerapan pembelajaran matematika bercirikan active knowledge sharing dengan pendekatan saintifik dapat meningkatkan sikap positif siswa terhadap matematika.

Tabel 9 Hasil angket sikap terhadap matematika siklus I dan siklus II

\begin{tabular}{llrrrr}
\hline \multicolumn{1}{c}{ Interval } & \multicolumn{1}{c}{ Kriteria } & Kondisi Awal & Target & Akhir Siklus I & Akhir Siklus II \\
\hline $\mathrm{X}>184,79$ & Sangat baik & $21,87 \%$ & $25 \%$ & $15,62 \%$ & $21,88 \%$ \\
$149,6<\mathrm{X} \leq 184,79$ & Baik & $71,87 \%$ & $75 \%$ & $75,00 \%$ & $78,12 \%$ \\
$114,4<\mathrm{X} \leq 149,6$ & Cukup & $0 \%$ & $0 \%$ & $9,38 \%$ & \\
$79,21<\mathrm{X} \leq 114,4$ & Kurang & $6,25 \%$ & $0 \%$ & $0 \%$ & \\
X $\leq 79,21$ & Sangat kurang & $0 \%$ & $0 \%$ & $0 \%$ & \\
\multicolumn{1}{c}{ Rata-rata } & & 150,2 (Baik) & & 162,63 (Baik) & 177,25 (Baik) \\
\hline
\end{tabular}

\section{Hasil tes kemampuan kognitif}

Berdasarkan hasil tes yang dilaksanakan pada setiap akhir siklus dapat dikatakan bahwa melalui pendekatan saintifik dengan strategi active knowedge sharing hasil tes kemampuan kognitif siswa menjadi lebih baik. Berikut ini disajikan tabel peningkatan tes kemampuan kognitif yang ditunjukkan dengan skor rata-rata tes pada akhir siklus I dan siklus II.

Berdasarkan tabel 10, skor rata-rata persentase ketuntasan tes kemampuan kognitif siswa mengalami peningkatan sebesar 7,98\%. Pada akhir siklus I persentase ketuntasan mencapai 78,13\% kemudian mengalami peningkatan pada akhir siklus II menjadi $84,37 \%$. Nilai ratarata kelas juga meningkat dari akhir siklus I dengan rata-rata 82,28 meningkat pada akhir siklus II dengan rata-rata 82,79.

Berdasarkan hasil penelitian yang telah dilakukan, kemampuan kognitif siswa dalam pembelajaran matematika yang menerapkan pendekatan saintifik dengan strategi active knowledge sharing mengalami peningkatan. Selain pada tingkat sikap terhadap matematika, kemampuan kognitif siswa juga mengalami peningkatan, namun persentase kenaikan kemampuan sikap siswa terhadap matematika lebih besar daripada persentase kenaikan kognitif siswa.

Tabel 10 Hasil tes kemampuan kognitif siklus I dan siklus II

\begin{tabular}{lrrrr}
\hline \multirow{2}{*}{ Keterangan } & \multicolumn{2}{c}{ Siklus I } & \multicolumn{2}{c}{ Siklus II } \\
\cline { 2 - 5 } & Pre-tes & Post-tes & Pre-tes & Post-tes \\
\hline Rata-rata kelas & 50,81 & 82,28 & 51.67 & 82,79 \\
Nilai tertinggi & 62 & 92 & 62 & 95 \\
Nilai terendah & 32 & 66 & 32 & 70 \\
Tuntas & 0 & 25 & 0 & 27 \\
Belum Tuntas & 32 & 7 & 32 & 5 \\
Persentase Ketuntasan & $0 \%$ & $78,13 \%$ & $0 \%$ & $84,37 \%$ \\
\hline
\end{tabular}




\section{KESIMPULAN DAN IMPLIKASI}

\section{Kesimpulan}

Penerapan pembelajaran bercirikan active knowledge sharing dengan pendekatan saintifik meningkatkan sikap terhadap matematika siswa kelas VIII MTs SMP Negeri 1 Ciawi. Strategi active knowledge sharing memberikan kesempatan kepada siswa untuk saling berbagi pengetahuan secara aktif. Kompetisi antar peserta didik dapat dikurangi karena siswa diajarkan untuk saling membantu teman dalam hal kegiatan belajar. Siswa diarahkan untuk berpikir kritis dan kreatif dalam menyelesaikan permasalahan matematika yang diberikan. Selain pada tingkat sikap terhadap matematika, kemampuan kognitif siswa juga mengalami peningkatan, namun persentase kenaikan kemampuan sikap siswa terhadap matematika lebih besar daripada persentase kenaikan kognitif siswa.

\section{Implikasi}

Pembelajaran bercirikan active knowledge sharing dengan pendekatan saintifik dapat meningkatkan sikap siswa terhadap matematika dan hasil belajar. Oleh karena itu pembelajaran bercirikan active knowledge sharing dengan pendekatan saintifik dapat digunakan sebagai salah satu alternatif dalam upaya meningkatkan sikap terhadap matematika dan hasil belajar siswa.

\section{UCAPAN TERIMA KASIH}

Ucapan terima kasih atas terselenggaranya penelitian ini kami sampaikan kepada RISTEKDIKTI yang telah memberikan pendanaan atas program Penelitian Dosen Pemula tahun anggaran 2017.

\section{DAFTAR PUSTAKA}

Atkin MJ and P Black. 2003. Ways of knowing in science and mathematics series. Teachers College Press, New York.

Hosnan M. 2014. Pendekatan saintifik dan kontekstual dalam pembelajaran abad 21 kunci sukses implementasi kurikulum 2013. Ghalia Indonesia, Bogor.

Kemendiknas. 2005. Peraturan Pemerintah Republik Indonesia Nomor 19, Tahun 2005, Tentang Standar Nasional Pendidikan.

Kemendikbud. 2013a. Lampiran Peraturan Menteri Pendidikan dan Kebudayaan Nomor 68, Tahun 2013, tentang Kerangka Dasar dan Struktur Kurikulum Sekolah Menengah Pertama/Madrasah Tsanawiyah.

Komara E. 2014. Belajar dan pembelajaran interaktif. Refika Aditama, Bandung.

Widoyoko EP. 2009. Evaluasi program pembelajaran panduan praktis bagi pendidik dan calon pendidik. Pustaka Pelajar, Yogyakarta. 